\title{
The Correlation between Second Stage (Childbearing) Family Development Task with Completeness of Polio Immunization in Working Area of Wara Utara KotaPublic Health Center in 2018
}

\author{
Ratnasari Iskandar ${ }^{1 *}$, Nur Asphina R Djano ${ }^{2}$, Rahmah Tahir ${ }^{2}$ \\ 1) Ners Profession at Mega Buana Palopo College of Health Sciences \\ 2) Public Health Mega Buana Palopo College of Health Sciences \\ rsariskandar@gmail.com \\ DOI: http://doi.org/10.29080/ihsp.v3i3S.281
}

\section{Keywords}

Family

development

task;

Polio.

\begin{abstract}
Background: The second stage of family development refers to the stage when a baby was born in a family of new couples. The second phase of the family starts from the birth of the first child until the baby becomes months old. This stage has a health concern in the fulfillment of its development task; namely, a type of primary immunization that is Polio immunization given completely in infants aged 1 - 4 months old Objective: to know the correlation of family development second stage task (childbearing family) with the of Polio immunization in infants in the Area of Wara Utara KotaPublic Health Centers in 2018. Method: This research used cross-sectional analytical correlation emphasizing on the time of measurement/observation of independent and dependent variable data assessed on a one time simultaneous basis. The population of this research was families with second stage. The sample was 74 people a purposive sampling method. Data analysis by Chi-Square test. Results: The result of statistical analysis resulted in $=0,002<\alpha=0,05$, so there was a correlation between family development task with the of Polio immunization. Conclusion: Second stage family development task is the transition stage of the individual role, become parents/a parent and form a permanent system. This stage has attention health in fulfilling tasks development, especially Immunization.
\end{abstract}

\section{Introduction}

Developmental tasks also relate to task expectations or specific roles at each stage to achieve basic family functions. The second stage in family growth and development, which is the stage when a baby is born in the middle of a new partner consisting of two individuals as a partner. Family stage II (childbearing family) starts from the birth of the first child until the baby is 30 months old. This second stage is the transition stage from the role of the individual to be a parent and forming a permanent system. This stage has health attention in fulfilling its development tasks, namely immunization of one type of basic immunization is Polio immunization that is given completely in infants aged 1-4 months (1).

Indonesia, together with countries in the Southeast Asia Region, has received Polio-Free Certificates from the World Health Organization (WHO) on 27 March 2014. However, despite being declared free of polio, the risk of spreading polio in Indonesia remains high as long as the wild polio virus is still circulating in the world and the risk factors for transmission still remain because the community's immunity is not optimal due to the presence of enclaves with low coverage of routine polio immunization for several years (2).

At present in Indonesia, there are still many children who have not received complete immunizations and have never received immunizations since they were. This causes them to easily to have contract with dangerous diseases because there is no immunity to the disease. Data from the Directorate of Disease Prevention and Control, the Ministry of Health of the Republic of Indonesia shows that since 20142016, there are around 1.7 million children who have not received immunizations or their immunization status is incomplete (2).

In order to form a high level of community immunity, high and evenly distributed basic and advanced immunizations are needed throughout the region, even to the village level. If the level of community immun 
is high, then not only children who get immunization but also the whole community will be protected. In order to achieve a high and evenly distributed immunization coverage in each region, the Minister of Health calls on all Regional Heads (1) to tackle carefully the main obstacles in each region in implementing immunization programs; (2) mobilizing resources in all related sectors including the private sector; and (3) increasing public awareness of the importance of complete routine immunization so that they are willing and able to visit immunization services (2).

Recapitulation of the implementation of polio pins Sulawesi Barat (82,7\%); Sulawesi Selatan (74,96\%); Sulawesi Utara (83,1\%); Sulawesi Tenggara (83,0\%); .Sulawesi Tengah (83,7\%); Gorontalo $(81,6 \%)(3)$.

To the village level. If the level of community immunity is high, then not only children who get immunization but also the whole community will be protected. In order to achieve a high and evenly distributed immunization coverage in each region, the Minister of Health calls on all Regional Heads (1) to tackle carefully the main obstacles in each region in implementing immunization programs; (2) to mobilize resources in all related sectors including the private sectors; and (3) to increase public awareness of the importance of complete routine immunization so that they are willing and able to visit immunization services (2).

The Ministry of Health together with the Health Office of all provinces and districts/cities have made efforts to ensure access to immunization services a tremote areas and difficult to reach cooperation with other cross sectors through a strategy to guarantee the availability of vaccines and vaccine chain equipment quality, training for health workers and efforts to improve public knowledge through various media and socialization through public service announcements (4).

However, even though national coverage has reached the target, coverage gaps in some regions still exist. There are stillthe same children once you have not received immunization or have not been fully immunized. According to estimates released by WHO / UNICEF in 2017, almost one million Indonesian children do not get any immunizations or complete immunization status (2).

Based on the completeness of the Polio immunization problem, the study was conducted which aimed to identify the relationship between childbearing family stages of development and the completeness of Polio immunization..

\section{Methods}

The research was conducted in June 2018 at the Wara Utara Kota Public Health Center. This research is cross-sectional study. This research used purposive sampling method with 74 people based on Inclusion Criteria, Have a KIA Handbook, and Cooperatif Parents. Exclusion criteria was a Childeren are not fostered by parents. Source of research data was primary data, measurement variable family deveopment task for second stage (childbearing) family was through interviews using questionnaires which adapted from Friedman's theory, the questionnaire consists of 18 items and used likert scale from criteria always (score 4), often (score 3), sometimes (score 2) and never (score 1), and had been tested for validity and relibility in previous studies. Measurement of completeness of polio immunization status was carried out using KIA handbook. In KIA handbook, we can find a record of toddler immunization as well as can find the status of polio immunization. The technique of data analysis used was a analysis which aimed to see the description of the frequency distribution of respondents' characteristics. The analysis aimed to see the effect of independent variables on the dependent variable using the Chi-Square test. Multivariate analysis was conducted to see the extent of the influence of each independent variable. Which in this case was second stage family development task and dependent variable in this case was completness polio immunization.

\section{Results \\ Univariate Analysis}

Table 1 showed the characteristics of 74 respondents, $36(48,7 \%)$ aged respondents were $25-27$ year, 37 (50\%) respondents graduate from senior high school, while in the aspect of baby's age, 20 (27\%) respondent had 8-age- month baby. 
Table 1 Respondent Distribution at 2018 Wara Utara Kota Public Health Center

\begin{tabular}{lll}
\hline Age (Year) & $\mathrm{n}$ & $(\%)$ \\
\hline Age & 3 & 4 \\
$19-21$ & 11 & 14,9 \\
$22-24$ & 36 & 48,7 \\
$25-27$ & 24 & 32,4 \\
$28-30$ & & \\
Level Education & 4 & 5,4 \\
Elementary School & 18 & 24,3 \\
Junior High School & 37 & 50 \\
Senior High School & 15 & 20 \\
University & & \\
& & 20,3 \\
Age Of Babies & 15 & 27 \\
7 month & 20 & 20,3 \\
8 month & 15 & 13,4 \\
9 month & 10 & 18,9 \\
10 month & 14 & 100 \\
11 month & & \\
\hline Total & 74 & \\
\hline
\end{tabular}

Source : Primary Data 2018

Table 2 showed the characteristics of respondents based on the variables studied. This table revealed that out of 74 respondents, $55(74,3 \%)$ had fulfilled the second stage family development task, for Polio Immunization, $64(86,5 \%)$ respondents had a baby"s with a complete polio immunization.

Table 2 Distribution of Respondents Based on second stage Family Development Tasks with Polio Immunization in 2018 Wara Utara Kota Public Health Centers

\begin{tabular}{lcc}
\hline Variable & (n) & $(\%)$ \\
\hline & & \\
Second Stage Family Development Task & & 74,3 \\
Fulfilled & 55 & 25,7 \\
Unfulfilled & 19 & \\
& & 86,5 \\
Polio Immunization & 64 & 13,5 \\
Complete & 10 & 100 \\
In complete & & \\
& 74 &
\end{tabular}

Source : Primary Data 2018

\section{Bivariate Analysis}

Table 3 showed that 55 respondents had family fulfillment second stage family development tasks, which is 52 people (94.5\%) who had babies with complete polio immunization and 3 people (5.5\%) were incomplete. Whereas 19 respondents whose second stage family development tasks were unfulfilled, which is 12 participants $(63.2 \%)$ had babies with complete Polio immunization and 7 participants (36.8\%) were incomplete. From the results of statistical analysis obtained the value of $\rho=0,002<0.05$, meaning that there is a relationship between second stage family development tasks and the completeness of Polio immunization. 
Table 3 The Correlation between Second Stage (Childbearing) Family development Task with Compliteness of Polio Immunization in Working Area of Wara Utara Kota Public Health Center in 2018.

\begin{tabular}{|c|c|c|c|c|c|c|c|}
\hline \multirow{2}{*}{$\begin{array}{l}\text { Family } \\
\text { Development } \\
\text { Task }\end{array}$} & & & \multicolumn{3}{|c|}{$\begin{array}{l}\text { Polio } \\
\text { Immunization }\end{array}$} & & \multirow[b]{2}{*}{$\mathrm{P}$-value } \\
\hline & Complete & & Incomplete & & Total & & \\
\hline & $\mathrm{f}$ & $\%$ & $\mathrm{~F}$ & $\%$ & $\mathrm{f}$ & $\%$ & ,002 \\
\hline Fulfilled & 52 & 94,5 & 3 & 5,5 & 55 & 100 & \\
\hline Unfilled & 12 & 63,2 & 7 & 36,8 & 19 & 100 & \\
\hline
\end{tabular}

Source : Primary Data 2018

\section{Discussion}

The correlation between second stage family development tasks with the completeness of Polio immunization is from the results of the research showing that respondents whose second stage family development tasks were fulfilled were. It is too long and wordy 55 people, of which there were 52 people had babies with complete Polio immunization and 3 people incomplete. Whereas 19 respondents whose family development tasks were not fulfilled, of which 12 had babies with complete Polio immunization and 7 were incomplete. The results of statistical analysis obtained the value of $p=, 002<\alpha=, 05$, meaning that there is a relationship between family development tasks and the completeness of polio immunization.

The task of family development stage II (childbearing family) relates significantly to the completeness of Polio immunization in infants supported by three development task indicators that are filled with good fulfillment:

1. Indicator of feelings of being a parent. The feeling of being a parent is related to the experience of being a parent and a statement about changing roles. Changes in roles and adaptation to new responsibilities as parents are more quickly learned by mothers than fathers. A mother will feel a child faster as a reality than a father. Indicators of discussion in the family. Discussions of couples in the family are needed to support the passage of a family that is just starting its new stage. Discussions in the family are needed because of greater material needs and the responsibility of the couple as parents of the baby. Discussions within the family are also needed in preparing for possible loss of income, changes in sleep habits, and reduced time for husband and wife to be together.

2. Indicator of family-gathering frequency. The role transition does not only occur in two individuals who become a other and a father, but also the parents of the couple who switch roles to become grandparents. The role of being a grandfather and grandmother can cause some obstacles with the role of being a parent. The role shift also involves the role of grandfather and grandmother, demanding a parallel relationship with extended family, namely the relationship between changing the role of being a father and mother with the role of being a grandfather and grandmother. The participation of grandfather and grandmother in stage II (childbearing family) family has a big influence on the running of a family.

Parents play an important role in completing basic infant immunization, because immunization is an effort to prevent infectious diseases. Therefore, prior to the emergence of a disease that can deplete the strength of family resources and funds, it is first to provide complete basic immunization to the baby so that it can prevent the infection from being attacked. According to Friedman and Suprajitno, parents need to know the state of health and changes experienced by family members. Because health is a family needs that must not be ignored because without health everything will have no meaning and because of health issue all the power of resources and family funds run out $(1,5)$

Family tasks in the health sector that need to be done are deciding the appropriate health measures for the family, utilizing the surrounding health facilities, including the role of parents to provide complete basic immunization for their babies. Because this includes the main family effort that is seeking help that is appropriate for the needs of the family.

\section{Conclusion and Suggestion}

Based on the previous result and discussion, it can be concluded that there is a correlation between second stage family development tasks and the completeness of Polio immunization. Second stage family development task is the transition stage of the individual role, being a parent and build a permanent system. This stage has attention health in fulfilling tasks development, especially Immunization. 


\section{References}

1. Friedman MM. Buku Ajar Keperawatan Keluarga : Riset, Teori danPraktek. Jakarta: EGC; 2010.

2. Dinas kesehatan Kota Palopo. 2017.

3. World Health Organization. Immunization Summary. A Statistical Reference Containing Data Through. 2010.

4. Kementrian Kesehatan RI. Cakupan Imunisasi Pada Bayi Menurut Provinsi Tahun 2017. Pusdatin Kementerian Kesehatan RI; 2017.

5. Suprajitno. Asuhan Keperawatan Keluarga Aplikasi dalam Praktik. Jakarta: EGC; 2012. 